\title{
Long-Term Survival Outcomes of Metabolically Supported Chemotherapy with Gemcitabine- Based or FOLFIRINOX Regimen Combined with Ketogenic Diet, Hyperthermia, and Hyperbaric Oxygen Therapy in Metastatic Pancreatic Cancer
}

\author{
Mehmet Salih lyikesici \\ Altinbas University, School of Medicine, Department of Medical Oncology, Bahcelievler, Turkey; ChemoThermia \\ Oncology Center, Istanbul, Turkey
}

\section{Keywords}

Metabolically supported chemotherapy - Ketogenic diet . Hyperthermia · Hyperbaric oxygen therapy · Pancreatic ductal carcinoma Metastatic disease

\begin{abstract}
Background: Despite introduction of new chemotherapeutic agents, outcomes of patients with metastatic pancreatic cancer are still poor. Metabolically supported chemotherapy (MSCT) is a novel approach targeting dysregulated energy mechanism of the tumor cell. Objectives: This study aimed to examine the efficacy of metabolically supported administration of chemotherapy combined with ketogenic diet, hyperthermia, and hyperbaric oxygen therapy (HBOT) in patients with metastatic pancreatic cancer. Method: This retrospective observational study included 25 patients with metastatic pancreatic ductal carcinoma (stage IV) who received MSCT (either gemcitabine-based or FOLFIRINOX regimen administered concomitantly with induced hypoglycemia) plus ketogenic diet, hyperthermia, and HBOT combination. Survival outcomes were evaluated. Results: During the mean follow-up duration of $25.4 \pm 19.3$ months, median overall survival and median progression-free survival were 15.8 months $(95 \% \mathrm{Cl}, 10.5-21.1)$ and 12.9 months $(95 \% \mathrm{Cl}$, 11.2-14.6), respectively. Age and gender did not have any effect on overall survival ( $p>0.05$ for all). Conclusions: MSCT administered together with ketogenic diet, hyperthermia, and HBOT appears to be a viable option with the potential
\end{abstract}

to improve survival outcomes in patients diagnosed with metastatic pancreatic cancer. Further research, particularly with larger comparative clinical trials, is warranted.

(C) 2019 The Author(s) Published by S. Karger AG, Basel

\section{Schlüsselwörter}

Metabolisch unterstützte Chemotherapie · Ketogene Ernährung · Hyperthermie $\cdot$ Hyperbare Sauerstofftherapie · Duktales Pankreaskarzinom . Metastasierung

\section{Zusammenfassung}

Hintergrund: Trotz der Einführung neuer Chemotherapeutika sind die Verlaufsaussichten von Patienten mit metastasierendem Pankreaskarzinom weiterhin ungünstig. Die metabolisch unterstützte Chemotherapie (metabolically supported chemotherapy, MSCT) ist ein neuartiger Ansatz, der auf den entgleisten Energiehaushalt der Tumorzelle abzielt. Ziele: Ziel dieser Studie war die Unter-

\section{karger@karger.com}

www.karger.com/cmr

Karger $\stackrel{\text { '⿳亠丷厂 }}{=}$

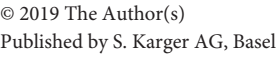

This article is licensed under the Creative Commons AttributionNonCommercial-NoDerivatives 4.0 International License (CC BYNC-ND) (http://www.karger.com/Services/OpenAccessLicense) Usage and distribution for commercial purposes as well as any
Mehmet Salih Iyikesici, MD

Altinbas Universitesi Tip Fakultesi, Tibbi Onkoloji Bolumu

Bahcelievler E-5 Karayolu Kultur Sokak No:1

TR-34180 Bahcelievler, Istanbul (Turkey)

E-Maildrmsi2018@gmail.com 
suchung der Wirksamkeit einer MSCT in Kombination mit ketogener Ernährung, Hyperthermie und hyperbarer Sauerstofftherapie (HBOT) bei Patienten mit metastasierendem Pankreaskarzinom. Methoden: In dieser retrospektiven Beobachtungsstudie betrachteten wir 25 Patienten mit metastasierendem duktalem Pankreaskarzinom (Stadium IV), die mit einer Kombination aus MSCT (Gemcitabin-haltiges oder FOLFIRINOX-Schema, verabreicht unter induzierter Hypoglykämie) mit ketogener Ernährung, Hyperthermie und HBOT behandelt wurden. Verschiedene Überlebenskennzahlen wurden ausgewertet. Ergebnisse: Während eines mittleren Nachbeobachtungszeitraums von 25,4 \pm 19,3 Monaten betrug das mediane Gesamtüberleben 15,8 Monate (95\%-KI: $10,5-21,1)$ und das mediane progressionsfreie Überleben 12,9 Monate (95\%-KI: 11,2-14,6). Alter und Geschlecht hatten keinen Einfluss auf das Gesamtüberleben ( $p>0,05$ für alle). Schlussfolgerungen: MSCT in Kombination mit ketogener Ernährung, Hyperthermie und HBOT scheint bei Patienten mit metastasierendem Pankreaskarzinom eine praktikable Behandlungsoption mit Potenzial zur Verbesserung von Überlebens-Outcomes zu sein. Weitere Forschung hierzu ist gerechtfertigt, insbesondere in Form größerer vergleichender klinischer Studien.

(C) 2019 The Author(s)

Published by S. Karger AG, Basel

\section{Introduction}

Pancreatic cancer is an aggressive and deadly disease with a poor outlook. It ranks fourth and fifth among cancer-related deaths in the US and Europe, respectively [1, 2]. Long-term survival is usually not expected; e.g., in Europe, age- and area-adjusted 5-year relative survival rate is $6 \%$ [3]. Owing to its rapid course, unavailability of early detection tests, and absence of recognizable symptoms and signs in early disease, many patients are diagnosed late in the disease course, either with metastatic or locally advanced disease [2].

Chemotherapy confers survival advantage over best supportive care in cases with advanced disease [4]. In patients with locally advanced and metastatic pancreatic cancer, gemcitabine monotherapy or gemcitabine-based combination therapies are recommended by recent guidelines [5]. Two recent meta-analyses demonstrated superior survival outcomes with gemcitabine-based combination therapies when compared to gemcitabine alone but with increased toxicity $[6,7]$. FOLFIRINOX regimen is also considered an option for these patients [8].

In 1924, Otto Warburg hypothesized that "cancer is a disease of metabolic dysregulation." Since then, this dysregulated energy metabolism evident in almost all tumor types where aerobic fermentation compensates for insufficient oxidative phosphorylation has been named the
"Warburg effect" [9-11]. Metabolic impairment characterized by glucose dependency and increased lactate production in cancer cells has been linked to mitochondrial dysfunction and genetic mutations [11-14]. This feature also forms the basis of fluorodeoxyglucose-PET scans used in the diagnosis and follow-up of cancer.

Based on this metabolic difference between cancer cells and normal cells, a novel chemotherapy administration method, namely metabolically supported chemotherapy (MSCT), has been developed [15-17], which involves a 12-hour fasting before each chemotherapy session and administration of insulin just prior to chemotherapy in an attempt to increase the efficacy of chemotherapeutic drugs by increasing membrane permeability [18] and for the development of mild hypoglycemia to cause an acute metabolic stress on cancer cells. Ketogenic diet is a supplementary approach also targeting metabolic vulnerability of cancer cells through decreasing the availability of glucose. Adapting a ketogenic diet has been shown to slow the progression of cancer [17, 19-25].

Another supplementary approach, hyperthermia, has been shown to increase the efficacy of radiotherapy and chemotherapy by sensitizing cancer cells to these therapies, and synergism between hyperthermia and many chemotherapeutic agents have already been demonstrated $[15,17,26-34]$.

Tumor hypoxia due to abnormal vasculature has cancer-promoting effects and has been associated with resistance to chemotherapy and radiotherapy [35-39]. During hyperbaric oxygen therapy (HBOT), oxygen is administered at high pressure resulting in better oxygenation of tissues. Better oxygenation has the potential to counteract such unfavorable consequences of hypoxia in tumor cells, thus improving the efficacy of chemotherapy. Evidence supporting its potential use comes from a number of experimental $[24,25,40-44]$ and clinical studies $[26,27$, 45].

Available evidence supports the potential benefits of MSCT, ketogenic diet, hyperthermia, and HBOT. A combination of the four could work synergistically by targeting several overlapping metabolic pathways and vulnerabilities of cancer cells.

This study aimed to examine the efficacy of MSCT combined with ketogenic diet, hyperthermia, and HBOT in patients with metastatic ductal pancreatic cancer and hypothesized that this combination therapy is associated with favorable survival and clinical outcomes.

\section{Materials and Methods}

Study Design and Patient Selection

This retrospective observational single-center study included 25 patients diagnosed with stage IV pancreatic cancer who received MSCT with a gemcitabine-based regimen or FOLFIRI- 
Fig. 1. Schematic representation of each chemotherapy session showing treatment order. Patients are admitted after $12 \mathrm{~h}$ of fasting. Upon admission, insulin is administered to obtain mild hypoglycemia, after which chemotherapy is administered. Hyperthermia and HBOT are administered within $24 \mathrm{~h}$ of chemotherapy application or both are administered on the next day. On a gemcitabine-based chemotherapy regimen, chemotherapy is administered on day 1 and day 8 of a 21 -day cycle, and on a FOLFIRINOX chemotherapy regimen, chemotherapy is administered on day 1 every 2 weeks. Ketogenic diet is adapted by the patients throughout the whole treatment period.

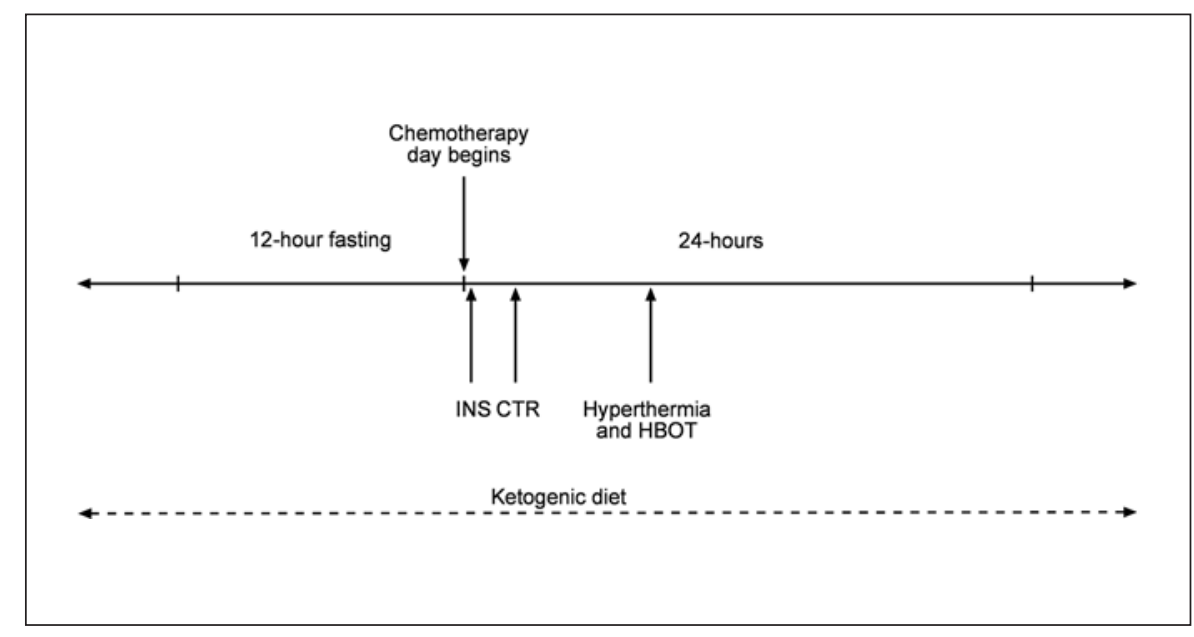

NOX between July 2012 and August 2014. In addition, patients adapted a ketogenic diet and received hyperthermia application and HBOT together with MSCT. Patients with metastatic pancreatic cancer at the time of admission were included in the study. Regardless of previous disease or treatment course, presentation with metastatic disease was considered the time of diagnosis. A prospectively maintained institutional database for MSCT was screened to identify eligible patients. Patients with biopsy-proven pancreatic cancer, measurable disease as defined by Response Evaluation Criteria in Solid Tumors version 1.1 (RECIST 1.1) [46], and radiologically proven stage IV disease were included for analyses. Patients eligible for chemotherapy were also considered eligible for other modalities (metabolic administration, ketogenic diet, HBOT, and hyperthermia) when making treatment planning. Patient and survival data were extracted from the records and analyzed. Primary endpoint was overall survival, whereas secondary endpoints were progression-free survival, response rates, and toxicity.

\section{MSCT Protocol}

Patients received either a standard gemcitabine-based regimen or the FOLFIRINOX regimen. Patients who previously progressed while receiving gemcitabine regimen preferentially received FOLFIRINOX regimen. Gemcitabine-based regimen included 1,000 $\mathrm{mg} / \mathrm{m}^{2}$ gemcitabine, $30 \mathrm{mg} / \mathrm{m}^{2}$ cisplatin, and $400 \mathrm{mg} / \mathrm{m}^{2}$ fluorouracil, which was administered on days 1 and 8 of a 21 -day cycle. FOLFIRINOX regimen included $85 \mathrm{mg} / \mathrm{m}^{2}$ oxaliplatin, $400 \mathrm{mg} / \mathrm{m}^{2}$ folinic acid, $180 \mathrm{mg} / \mathrm{m}^{2}$ irinotecan, and fluorouracil $\left(400 \mathrm{mg} / \mathrm{m}^{2}\right.$ bolus then $2,400 \mathrm{mg} / \mathrm{m}^{2}$ over $46 \mathrm{~h}$ ), administered all on day 1 and then repeated every 2 weeks. Patients received these chemotherapy regimens until death as far as they tolerated. In case of disease progression as assessed by PET/CT imaging, patients receiving gemcitabine-based regimen were switched to FOLFIRINOX chemotherapy.

Patients were encouraged to consume a ketogenic diet throughout the treatment period. Before each chemotherapy session, patients fasted for $12 \mathrm{~h}$. In addition, they received regular insulin (Humulin ${ }^{\circledR} \mathrm{R}$ ) as well as $45.5 \mathrm{mg}$ pheniramine maleate and 0.25 mg palonosetron $\mathrm{HCl}$, as premedication just prior to each chemotherapy administration. Insulin doses ranged between 5-20 IU with the aim to achieve a state of mild hypoglycemia for normoglycemic (nondiabetic) patients $(50-60 \mathrm{mg} / \mathrm{dL}$ blood glucose levels) [15-17]. Hypoglycemia target was higher in patients with diabetes, corresponding to mild hypoglycemia based on the glycemic status of the patient. All patients were closely monitored for hypo- glycemia signs/symptoms and blood glucose levels by experienced staff and an i.v. line for dextrose administration was always kept open. Chemotherapy administration was initiated together with oral sugar intake following the achievement of target blood sugar level.

Following each MSCT administration, patients received one session of hyperthermia and HBOT. Each hyperthermia session lasted for $60 \mathrm{~min}$. OncoTherm EHY-3010 HT device (OncoTherm, Troisdorf, Germany) was used to increase the temperature of the tumoral region gradually. This device uses a modulated electrohyperthermia approach to specifically heat malignant cells and provides effective heat within the tumor tissue while preserving healthy surrounding tissues including the skin. Indirect temperature estimations are made based on the energy applied. The objective of hyperthermia was to obtain a tumoral tissue temperature over $43^{\circ} \mathrm{C}$ at the tumor site. A large enough mobile electrode positioned over the tumoral region was used based on each individual patient's condition to cover the primary tumor and metastases. In case the disease was limited to the abdomen, a $30 \times 40 \mathrm{~cm}$ mobile electrode was used. When the disease was also extended to the thorax, a larger $40 \times 50 \mathrm{~cm}$ mobile electrode was used to cover the tumoral area. Metastases outside the abdomen and thoracic cavity were not targeted. Per instructions of the manufacturer, the power was set at $110 \mathrm{~W}$ for the $30 \times 40 \mathrm{~cm}$ mobile electrode and at $130 \mathrm{~W}$ for the $40 \times 50 \mathrm{~cm}$ mobile electrode. At the end of a 60 -min session, the total energy applied was on average 400,000 Joules for the $30 \times$ $40 \mathrm{~cm}$ mobile electrode and 460,000 Joules for the $40 \times 50 \mathrm{~cm}$ mobile electrode.

Quamvis 320 hyperbaric oxygen chamber (OxyHealth, California, US) was used for each 60-min HBOT session, during which the patient was subjected to 1.5 atmospheres of pressure. Figure 1 shows a schematic representation of treatment order during each chemotherapy session.

\section{Assessment of Toxicity}

Evaluation of toxicity was done using Common Terminology Criteria for Adverse Events version 4.03 (CTCAE v4.03) [47]. Adverse events experienced by each patient per cycle were recorded and for each patient, the worst overall adverse event grade per event type throughout the study period was documented.

\section{Statistical Analysis}

Data were analyzed using IBM SPSS Statistics version 21.0 software (SPSS Inc., Chicago, IL, USA). Overall survival was defined as the time elapsed between the date of diagnosis of metastatic dis- 
Table 1. Demographical and clinical characteristics of the patients

\begin{tabular}{lc}
\hline Characteristic & $N=25$ \\
\hline Median age (range), years & $61(41-81)$ \\
Male gender & $17(68.0)$ \\
Chemotherapy & $7(28.0)$ \\
$\quad$ Only gemcitabine-based & $10(40.0)$ \\
Only FOLFIRINOX & $8(32.0)$ \\
\hline Switch to FOLFIRINOX* & \\
\hline
\end{tabular}

Unless otherwise stated, data is presented as $n(\%) .{ }^{*}$ Patients receiving gemcitabine-based regimen were switched to FOLFIRINOX chemotherapy in case of disease progression.

ease and death from any cause. Patients alive at the last follow-up were censored. Progression-free survival was defined as the time elapsed between the date of diagnosis of metastatic disease and disease progression or death from any cause. Patients alive and free from progression at the last follow-up were censored. Survival rates were estimated using Kaplan-Meier analysis, and univariate comparisons were performed using log-rank test. Two-sided $p$ values $<0.05$ were considered an indication of statistical significance.

\section{Results}

Table 1 shows demographical and clinical characteristics of the patients. Median age was 61 years (range, 4181). More than two-thirds of the patients were male (68.0\%). Tumor response rates at 3 months were as follows: complete response, 8 patients (32\%); partial response, 15 patients (60\%); stable disease, 1 patient (4\%); progressive disease, 1 patient (4\%).

Mean duration of follow-up was $25.4 \pm 19.3$ months (median 15.8, range 7.2-69.7 months). Median overall survival and median progression-free survival were 15.8 months (95\% CI, 10.5-21.1) and 12.9 months (95\% CI, 11.2-14.6), respectively. Figure 2 shows Kaplan-Meier curves for all patients.

Table 2 shows overall and progression-free survival rates by patient characteristics. Patients who initially received gemcitabine regimen had better survival outcomes compared to the patients who initially received FOLFIRINOX. Age and gender did not have any effect on survival outcomes.

During the study period, the following hematological toxicities developed: grade 3/4 neutropenia, $9(36 \%)$ patients; febrile neutropenia, 1 (4\%) patient; grade 4 thrombocytopenia requiring platelet transfusion, 4 (16\%) patients; grade 3 anemia requiring RBC transfusions, 7 $(28 \%)$ patients. Overall, non-hematological toxicities were rare. Two (8\%) patients had grade 3 diarrhea. During the study period, no adverse effects or toxicities related to fasting, hypoglycemia, ketogenic diet, hyperthermia, or HBOT were observed.

\section{Discussion}

In this study, administration of MSCT together with ketogenic diet, hyperthermia, and HBOT resulted in encouraging survival outcomes in patients with metastatic pancreatic cancer. To date, only few studies have examined this combination in several malignant conditions. The findings of this study have clinical implications in terms of both patient care and future research on treatment modalities complementary to conventional chemotherapy.

In an earlier report, chemotherapy was associated with a significantly better but limited survival when compared to best supported care (median survival rate, 6 vs. 2.5 months) [4]. Later, better rates have been reported with different chemotherapy regimens, but results are far from being satisfactory. A meta-analysis comparing gemcitabine-based combinations and gemcitabine alone included 26 studies and 8,808 patients with unresectable pancreatic cancer and demonstrated a survival advantage for combination therapy. In that study, median overall survival ranged between 5.5 and 9 months in the gemcitabine-based combination therapy group [7]. In a large randomized trial comparing FOLFIRINOX and gemcitabine in patients with metastatic pancreas cancer, the median overall survival was 11.1 months and 6.8 months in the FOLFIRINOX group and gemcitabine group, respectively [8]. A recent review summarizes the findings of the randomized controlled trials that compared various combination therapies with gemcitabine monotherapy in patients with advanced metastatic cancer (not only metastatic cancer, as it is the case in the present study) and reported median survival rates ranging between 5.1 and 11.1 months and response rates ranging between 7 and $31.6 \%$ [48]. In this study, we administered similar chemotherapeutic agents but used a metabolically supported approach in combination with ketogenic diet, hyperthermia, and HBOT and achieved an encouraging overall median survival rate of 15.8 months and progression-free survival rate of 12.9 months. In addition, response rates at 3 months were also encouraging.

Although patients who received gemcitabine regimen first at the beginning of this study had better outcomes, this does not seem to represent a true difference between two chemotherapy regimens since patients who previously progressed while receiving gemcitabine regimen preferentially received FOLFIRINOX regimen as the initial therapy, thus representing a group of patients with different clinical course. Large prospective randomized studies are warranted to test any true difference between the two regimens.

MSCT is an approach aiming to supplement the chemotherapy regimen in terms of efficacy and safety. Induction of hypoglycemia to target increased glucose de- 


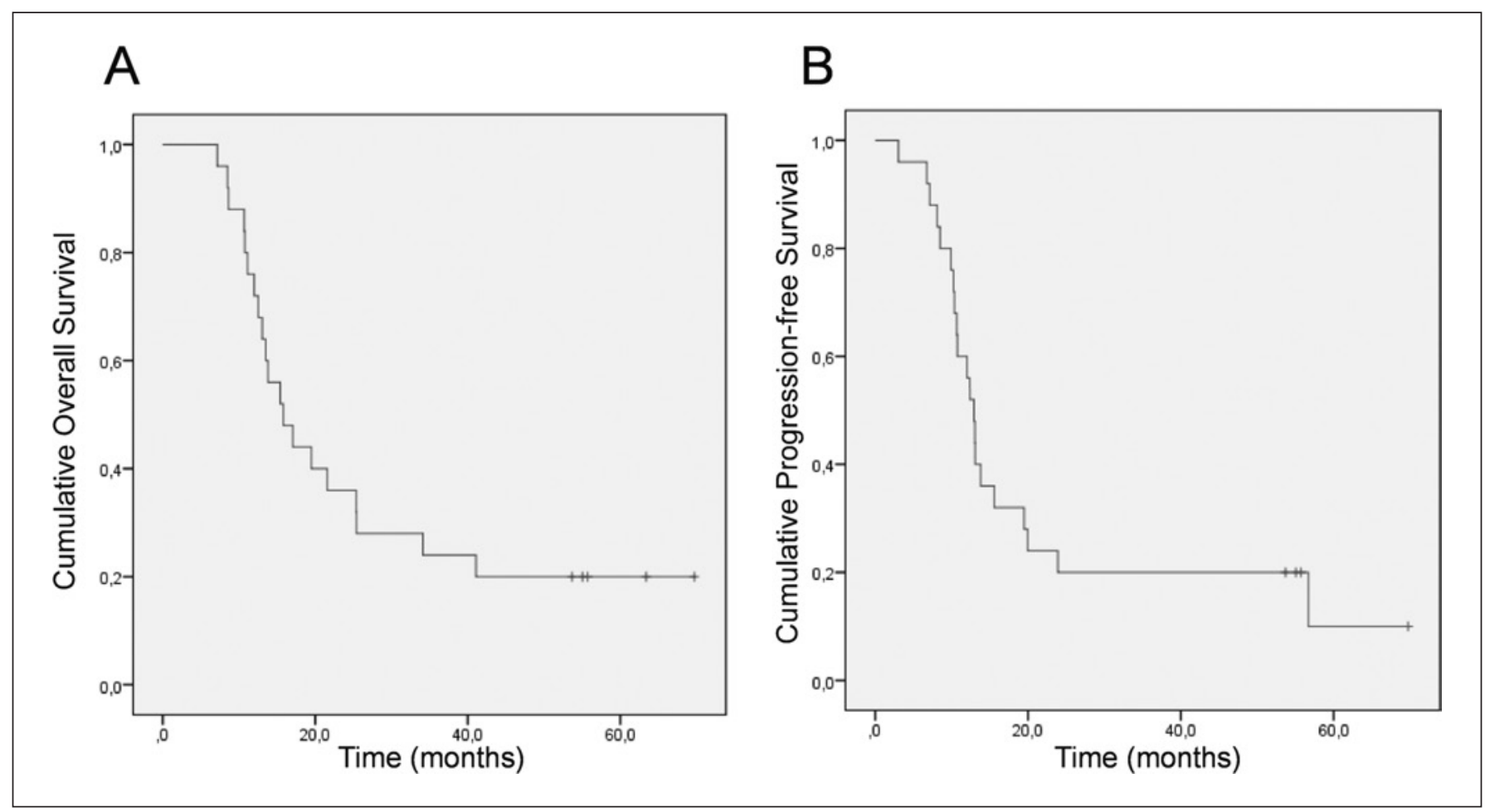

Fig. 2. Kaplan Meier curves for overall survival (A) and progression-free survival (B).

Table 2. Survival rates by patient characteristics

\begin{tabular}{|c|c|c|c|}
\hline Characteristic & Mean (95\% CI), months & Median (95\% CI), months & $p$ value $^{a}$ \\
\hline \multicolumn{4}{|l|}{ Overall survival } \\
\hline All patients $(n=25)$ & $27.4(18.6-36.3)$ & $15.8(10.5-21.1)$ & \\
\hline \multicolumn{4}{|l|}{ Age } \\
\hline$\leq \operatorname{median}(n=13)$ & $23.6(13.4-33.9)$ & $15.4(11.6-19.3)$ & \multirow[t]{2}{*}{0.521} \\
\hline$>$ median $(n=12)$ & $30.4(17.1-43.9)$ & $19.5(6.3-32.7)$ & \\
\hline \multicolumn{4}{|l|}{ Gender } \\
\hline Male $(n=17)$ & $29.7(18.4-41.0)$ & $15.8(10.4-21.2)$ & \multirow[t]{2}{*}{0.540} \\
\hline Female $(n=8)$ & $20.6(11.1-30.1)$ & $13.8(5.5-22.1)$ & \\
\hline \multicolumn{4}{|l|}{ Initial chemotherapy regime* } \\
\hline Gemcitabine-based $(n=15)$ & $34.7(21.9-47.4)$ & $21.6(11.1-32.1)$ & \multirow[t]{2}{*}{0.016} \\
\hline FOLFIRINOX $(n=10)$ & $16.6(9.5-23.7)$ & $12.0(9.2-14.8)$ & \\
\hline \multicolumn{4}{|l|}{ Progression-free survival } \\
\hline All patients $(n=25)$ & $22.3(13.9-30.7)$ & $12.9(11.2-14.6)$ & \\
\hline \multicolumn{4}{|l|}{ Age } \\
\hline$\leq \operatorname{median}(n=13)$ & $18.1(8.4-27.8)$ & $12.0(8.4-15.6)$ & \multirow[t]{2}{*}{0.217} \\
\hline$>$ median $(n=12)$ & $27.4(13.5-41.4)$ & $13.8(8.4-19.2)$ & \\
\hline \multicolumn{4}{|l|}{ Gender } \\
\hline Male $(n=17)$ & $24.0(13.2-34.7)$ & $12.9(9.8-16.0)$ & \multirow[t]{2}{*}{0.744} \\
\hline Female $(n=8)$ & $17.6(7.5-27.7)$ & $12.4(7.5-17.3)$ & \\
\hline \multicolumn{4}{|l|}{ Initial chemotherapy regime* } \\
\hline Gemcitabine-based $(n=15)$ & $29.6(17.1-42.1)$ & $13.8(5.5-22.1)$ & \multirow[t]{2}{*}{0.023} \\
\hline FOLFIRINOX $(n=10)$ & $11.3(7.8-14.8)$ & $10.7(10.1-11.2)$ & \\
\hline
\end{tabular}

${ }^{a}$ Log-rank test. ${ }^{*}$ Regardless of which treatment(s) the patient received before the diagnosis of metastatic disease, the first treatment that the patient received at the beginning of this study. 
pendency of the tumor cell is the main objective of MSCT, which in turn causes acute metabolic stress in tumor cells due to the low availability of circulating glucose [9-14]. In addition, the insulin molecule itself may have a direct contribution to the efficacy and safety of the MSCT. Insulin increases membrane fluidity and permeability; therefore, it has the potential to improve the transport of chemotherapeutics into the tumor cell and increase their cytotoxic effects [49-51]. Insulin-drug complexes internalized by receptor-mediated endocytosis seems to be important in this facilitated transport [52-55]. Insulin-receptor interaction would also prolong the S-phase of the cell cycle, therefore rendering cancer cells more susceptible to the cytotoxic effects of chemotherapeutics [56]. It is of note to emphasize that the effect of insulin at the cellular level, either in terms of facilitated transport of chemotherapeutics or prolonged S-phase, would be more pronounced in tumor cells compared to healthy cells owing to the increased amount of insulin and insulin-like growth factor (IGF) receptors on their membranes $[57,58]$. This difference in receptor density would improve treatment specificity through augmented cytotoxic effects in tumor cells in contrast to relative protection of normal cells. So far, several studies have provided supporting evidence for the benefits of integrating metabolic support to chemotherapy regimens in patients with advanced cancer. The preliminary findings of this study were reported elsewhere previously with promising outcomes [16]. In addition, complete clinical and pathological response was achieved in an 81-year-old patient with locally advanced rectal cancer using FOLFOX6 regimen with MSCT approach [15]. In a stage IV triple-negative breast cancer patient treated with an MSCT regimen combining docetaxel, doxorubicin, and cyclophosphamide, complete clinical, radiological, and pathological response was also achieved [17].

Ketogenic diet, another additional modality used in this study, also targets glucose dependency of the tumor cell. Several preclinical studies and case reports have provided support for its potential role in the treatment of cancer [17, 19-25, 59-64]. Hyperthermia is itself cytotoxic and potentially sensitizes the tumor cell to chemotherapeutics. HBOT exploits the reliance of tumor cells on glycolysis, which contributes to the antioxidant activity responsible for the resistance of the tumor to pro-oxidant chemotherapy and radiation therapies [65]. Various combinations of these therapies have been shown to act synergistically and potentially complement the conventional therapies in different cancers $[11,17,24-32$, 42-45]. Ohguri et. al. [26] added hyperthermia and HBOT to the chemotherapy regimen in NSCLC patients with multiple pulmonary metastases and obtained promising results.
To the best of our knowledge, to date several studies have tested combinations of chemotherapy and hyperthermia (one of the components of our treatment protocol) in the treatment of pancreatic cancer. In a recent study from China, patients with pancreatic cancer received deep regional hyperthermia in addition to modified FOLFIRINOX regimen and hyperthermia treatment was performed during chemotherapy for $45 \mathrm{~min}$ in each session [66]. In that study, $82 \%$ of the cases had metastatic disease. Patient group and mode of hyperthermia administration is similar to our study. An overall survival rate of 17 months was reported, which is also similar to our findings. On the other hand, progression-free survival was relatively lower (4 months). In another study with locally advanced or metastatic pancreatic cancer patients with malignant ascites, mean overall survival of 6.5 months has been reported with the combination of chemotherapy (systemic and intraperitoneal) and abdominal hyperthermia [67]. Several earlier studies also reported encouraging results with the combination of chemotherapy and hyperthermia in the treatment of pancreatic cancer [68-71]. In addition, a recent study examined the same combinational treatment protocol used in this study (MSCT, ketogenic diet, hyperthermia, and HBOT) in patients with stage IV non-small cell lung cancer with a mean overall survival rate of 42.9 months, supporting the notion that targeting multiple pathways and cellular vulnerabilities may bring about remarkable improvements in the outcomes of patients with advanced cancer [72].

Regarding the timings of HBOT and hyperthermia, they are similar across several previous studies testing them in combination with chemotherapy. In the study by He et al. [66] for example, hyperthermia treatment was performed during chemotherapy for $45 \mathrm{~min}$. Ohguri et al. [26] used HBOT and hyperthermia at each chemotherapy session. Iyikesici et al. [72] administered HBOT and hyperthermia just after chemotherapy. The rationale is to target multiple vulnerabilities of the tumor cell simultaneously and provide the highest possible stress on malignant cells.

The low sample size of this study might have prevented achieving sufficient power to detect survival differences between subgroups, which may be regarded as a major limitation. In addition, retrospective design is still another limitation, although all patients evaluated were treated uniformly and underwent systemic follow-up based on standard, predefined guidelines. Another limitation of the study is the lack of any quality of life measurements, which is planned to be incorporated into our future studies with this combinational treatment modality. However, observed safety and feasibility of the additional modalities does not seem to unfavorably effect the quality of life in this group of patients.
Iyikesici 
It is of note to emphasize that this study is preliminary in nature. Since we have some evidence on potential benefit of each component, we combine them in an attempt to provide best possible care for patients receiving treatment in our institution and this is the overall evaluation of the outcomes. Each component has some rationale based on previous studies, but relative contribution of each component may be subject to future larger prospective studies.

Advanced cancer is mostly associated with poor prognosis and available treatment modalities are limited. This study emphasizes that complementary therapies added to the conventional chemotherapy may be a viable option, particularly if they have a biochemical or pharmacological rationale.

\section{Conclusion}

Findings of this study suggest that MSCT administered together with ketogenic diet, hyperthermia, and HBOT is a viable option with the potential to improve survival outcomes of patients diagnosed with metastatic ductal pancreatic cancer. Further research and comparative clinical trials are warranted.

\section{Statement of Ethics}

Due to the retrospective nature of the study, institutional review board approval was not required. The authors have no ethical conflicts to disclose.

\section{Disclosure Statement}

The authors have no conflicts of interest to declare.

\section{Funding Sources}

This research received no specific grant from any funding agency in the public, commercial, or not-for-profit sectors.

\section{Author Contributions}

The author of the manuscript made substantial contributions to the conception/design of the work and the acquisition, analysis, and interpretation of data, drafted the work and revised it critically for important intellectual content, approved the final version to be published, and agreed to be accountable for all aspects of the work in ensuring that questions related to the accuracy or integrity of any part of the work are appropriately investigated and resolved.

\section{References}

1 Siegel RL, Miller KD, Jemal A. Cancer Statistics, 2017. CA Cancer J Clin. 2017 Jan;67(1): 7-30.

2 Seufferlein T, Bachet JB, Van Cutsem E, Rougier P; ESMO Guidelines Working Group. Pancreatic adenocarcinoma: ESMO-ESDO Clinical Practice Guidelines for diagnosis, treatment and follow-up. Ann Oncol. 2012 Oct;23 Suppl 7:vii33-40.

3 Sant M, Allemani C, Santaquilani M, Knijn A, Marchesi F, Capocaccia R; EUROCARE Working Group. EUROCARE-4. Survival of cancer patients diagnosed in 1995-1999. Results and commentary. Eur J Cancer. 2009 Apr;45(6):931-91.

4 Glimelius B, Hoffman K, Sjödén PO, Jacobsson G, Sellström H, Enander LK, et al. Chemotherapy improves survival and quality of life in advanced pancreatic and biliary cancer. Ann Oncol. 1996 Aug;7(6):593-600.

5 Tempero MA, Malafa MP, Al-Hawary M, Asbun $\mathrm{H}$, Bain A, Behrman SW, et al. Pancreatic Adenocarcinoma, Version 2.2017, NCCN Clinical Practice Guidelines in Oncology. J Natl Compr Canc Netw. 2017 Aug;15(8): 1028-61.

6 Ciliberto D, Botta C, Correale P, Rossi M, Caraglia M, Tassone $\mathrm{P}$, et al. Role of gemcitabine-based combination therapy in the management of advanced pancreatic cancer: a meta-analysis of randomised trials. Eur Cancer. 2013 Feb;49(3):593-603.
7 Sun C, Ansari D, Andersson R, Wu DQ. Does gemcitabine-based combination therapy improve the prognosis of unresectable pancreatic cancer? World J Gastroenterol. 2012 Sep; 18(35):4944-58.

8 Conroy T, Desseigne F, Ychou M, Bouché O, Guimbaud R, Bécouarn Y, et al.; Groupe Tumeurs Digestives of Unicancer; PRODIGE Intergroup. FOLFIRINOX versus gemcitabine for metastatic pancreatic cancer. $\mathrm{N}$ Engl J Med. 2011 May;364(19):1817-25.

9 Warburg OK. Über den Stoffwechsel der Carcinomzelle. Biochem Z. 1924;152:309-44.

10 Warburg O. On the origin of cancer cells. Science. 1956 Feb;123(3191):309-14.

11 Seyfried TN, Shelton LM. Cancer as a metabolic disease. Nutr Metab (Lond). 2010 Jan; 7(1):7.

12 Gillies RJ, Robey I, Gatenby RA. Causes and consequences of increased glucose metabolism of cancers. J Nucl Med. 2008 Jun;49 Suppl 2:24S-42S.

13 Frezza C, Pollard PJ, Gottlieb E. Inborn and acquired metabolic defects in cancer. $\mathrm{J} \mathrm{Mol}$ Med (Berl). 2011 Mar;89(3):213-20.

14 Bayley JP, Devilee P. The Warburg effect in 2012. Curr Opin Oncol. 2012 Jan;24(1):62-7.

15 Iyikesici MS, Slocum A, Turkmen E, Akdemir O, Slocum AK, Berkarda FB. Complete response of locally advanced (stage III) rectal cancer to metabolically supported chemoradiotherapy with hyperthermia. Int J Cancer Res Mol Mech. 2016;2(1):1-4.
16 Iyikesici MS, Slocum A, Turkmen E, Akdemir $\mathrm{O}$, Slocum AK, Ipek T, et al. Long-term outcomes of the treatment of unresectable (Stage III - IV) ductal pancreatic adenocarcinoma using metabolically supported chemotherapy (MSCT): a retrospective study. JOP. 2015; 17(1):36-41.

17 İyikesici MS, Slocum AK, Slocum A, Berkarda FB, Kalamian M, Seyfried TN. Efficacy of Metabolically Supported Chemotherapy Combined with Ketogenic Diet, Hyperthermia, and Hyperbaric Oxygen Therapy for Stage IV Triple-Negative Breast Cancer. Cureus. 2017 Jul;9(7):e1445.

18 Ayre SG, Garcia y Bellon DP, Garcia DP Jr. Insulin, chemotherapy, and the mechanisms of malignancy: the design and the demise of cancer. Med Hypotheses. 2000 Oct;55(4): 330-4.

19 Seyfried TN, Flores R, Poff AM, D’Agostino DP, Mukherjee P. Metabolic therapy: a new paradigm for managing malignant brain cancer. Cancer Lett. 2015 Jan;356(2 2 Pt A):289300.

20 Stafford P, Abdelwahab MG, Kim DY, Preul MC, Rho JM, Scheck AC. The ketogenic diet reverses gene expression patterns and reduces reactive oxygen species levels when used as an adjuvant therapy for glioma. Nutr Metab (Lond). 2010 Sep;7(1):74. 
21 Masko EM, Thomas JA 2nd, Antonelli JA, Lloyd JC, Phillips TE, Poulton SH, et al. Lowcarbohydrate diets and prostate cancer: how low is "low enough"? Cancer Prev Res (Phila). 2010 Sep;3(9):1124-31.

22 Zuccoli G, Marcello N, Pisanello A, Servadei F, Vaccaro S, Mukherjee P, et al. Metabolic management of glioblastoma multiforme using standard therapy together with a restricted ketogenic diet: case Report. Nutr Metab (Lond). 2010 Apr;7(1):33.

23 Zhou W, Mukherjee P, Kiebish MA, Markis WT, Mantis JG, Seyfried TN. The calorically restricted ketogenic diet, an effective alternative therapy for malignant brain cancer. Nutr Metab (Lond). 2007 Feb;4(1):5.

24 Poff AM, Ari C, Seyfried TN, D’Agostino DP. The ketogenic diet and hyperbaric oxygen therapy prolong survival in mice with systemic metastatic cancer. PLoS One. 2013 Jun; 8(6):e65522.

25 Poff AM, Ward N, Seyfried TN, Arnold P, D'Agostino DP. Non-Toxic Metabolic Management of Metastatic Cancer in VM Mice: Novel Combination of Ketogenic Diet, Ketone Supplementation, and Hyperbaric Oxygen Therapy. PLoS One. 2015 Jun; 10(6):e0127407.

26 Ohguri T, Imada H, Narisada H, Yahara K, Morioka T, Nakano K, et al. Systemic chemotherapy using paclitaxel and carboplatin plus regional hyperthermia and hyperbaric oxygen treatment for non-small cell lung cancer with multiple pulmonary metastases: preliminary results. Int J Hyperthermia. 2009 Mar; 25(2):160-7.

27 Ohguri T, Kunugita N, Yahara K, Imada H, Uemura $H$, Shinya N, et al. Efficacy of hyperbaric oxygen therapy combined with mild hyperthermia for improving the anti-tumour effects of carboplatin. Int J Hyperthermia. 2015; 31(6):643-8.

$28 \mathrm{Xu}$ MJ, Alberts DS. Potentiation of platinum analogue cytotoxicity by hyperthermia. Cancer Chemother Pharmacol. 1988;21(3):1916.

29 Herman TS, Teicher BA, Chan V, Collins LS, Abrams MJ. Effect of heat on the cytotoxicity and interaction with DNA of a series of platinum complexes. Int J Radiat Oncol Biol Phys. 1989 Feb;16(2):443-9.

30 Othman T, Goto S, Lee JB, Taimura A, Matsumoto T, Kosaka M. Hyperthermic enhancement of the apoptotic and antiproliferative activities of paclitaxel. Pharmacology. 2001 May;62(4):208-12.

31 Cividalli A, Cruciani G, Livdi E, Pasqualetti P Tirindelli Danesi D. Hyperthermia enhances the response of paclitaxel and radiation in a mouse adenocarcinoma. Int J Radiat Oncol Biol Phys. 1999 May;44(2):407-12.

32 Zoul Z, Filip S, Melichar B, Dvorák J, Odrázka K, Petera J. Weekly paclitaxel combined with local hyperthermia in the therapy of breast cancer locally recurrent after mastectomy-a pilot experience. Onkologie. 2004 Aug;27(4): 385-8.

33 Moyer HR, Delman KA. The role of hyperthermia in optimizing tumor response to regional therapy. Int J Hyperthermia. 2008 May;24(3):251-61.
34 Jones EL, Samulski TV, Vujaskovic Z, Leonard RP, Dewhirst MW. Hyperthermia. In: Perez CA, Brady LW, Halperin WC, SchmidtUllrich RK, editors. Principles and practice of radiation oncology. 4th ed. Philadelphia: Lippincott Williams \& Wilkins; 2003. pp. 699735

35 Wouters BG, van den Beucken T, Magagnin MG, Lambin P, Koumenis C. Targeting hypoxia tolerance in cancer. Drug Resist Updat. 2004 Feb;7(1):25-40.

36 Vaupel P, Mayer A, Höckel M. Tumor hypoxia and malignant progression. Methods Enzymol. 2004;381:335-54.

37 Vaupel P, Harrison L. Tumor hypoxia: causative factors, compensatory mechanisms, and cellular response. Oncologist. 2004;9 Suppl 5: 4-9.

38 Hoogsteen IJ, Marres HA, van der Kogel AJ, Kaanders JH. The hypoxic tumour microenvironment, patient selection and hypoxiamodifying treatments. Clin Oncol (R Coll Radiol). 2007 Aug;19(6):385-96.

39 Vaupel P, Thews O, Hoeckel M. Treatment resistance of solid tumors: role of hypoxia and anemia. Med Oncol. 2001;18(4):243-59.

40 Stuhr LE, Raa A, Oyan AM, Kalland KH, Sakariassen PO, Petersen K, et al. Hyperoxia retards growth and induces apoptosis, changes in vascular density and gene expression in transplanted gliomas in nude rats. J Neurooncol. 2007 Nov;85(2):191-202.

41 Moen I, Øyan AM, Kalland KH, Tronstad KJ, Akslen LA, Chekenya M, et al. Hyperoxic treatment induces mesenchymal-to-epithelial transition in a rat adenocarcinoma model. PLoS One. 2009 Jul;4(7):e6381.

42 Stuhr LE, Iversen VV, Straume O, Maehle BO, Reed RK. Hyperbaric oxygen alone or combined with 5-FU attenuates growth of DMBA-induced rat mammary tumors. Cancer Lett. 2004 Jul;210(1):35-40.

43 Petre PM, Baciewicz FA Jr, Tigan S, Spears JR. Hyperbaric oxygen as a chemotherapy adjuvant in the treatment of metastatic lung tumors in a rat model [discussion]. J Thorac Cardiovasc Surg. 2003 Jan;125(1):85-95

44 Al-Waili NS, Butler GJ, Beale J, Hamilton RW, Lee BY, Lucas P. Hyperbaric oxygen and malignancies: a potential role in radiotherapy, chemotherapy, tumor surgery and phototherapy. Med Sci Monit. 2005 Sep;11(9):RA27989.

45 Bennett M, Feldmeier J, Smee R, Milross C. Hyperbaric oxygenation for tumour sensitisation to radiotherapy: a systematic review of randomised controlled trials. Cancer Treat Rev. 2008 Nov;34(7):577-91.

46 Schwartz LH, Litière S, de Vries E, Ford R, Gwyther S, Mandrekar S, et al. RECIST 1.1-Update and clarification: from the RECIST committee. Eur J Cancer. 2016 Jul;62: $132-7$.

47 Common Terminology Criteria for Adverse Events (CTCAE): National Cancer Institute; 2010 [cited 2018 July 23]. Available from: https://ctep.cancer.gov/protocoldevelopment/electronic_applications/ctc.htm

48 Lee HS, Park SW. Systemic Chemotherapy in Advanced Pancreatic Cancer. Gut Liver. 2016 May;10(3):340-7.
49 Shinitzky M, Henkart P. Fluidity of cell membranes-current concepts and trends. Int Rey Cytol. 1979;60:121-47.

50 Demetrius LA, Coy JF, Tuszynski JA. Cancer proliferation and therapy: the Warburg effect and quantum metabolism. Theor Biol Med Model. 2010 Jan;7(1):2.

51 Schilsky RL, Bailey BD, Chabner BA. Characteristics of membrane transport of methotrexate by cultured human breast cancer cells. Biochem Pharmacol. 1981 Jun;30(12):153742.

52 Gasparro FP, Knobler RM, Yemul SS, Bisaccia E, Edelson RL. Receptor-mediated photo-cytotoxicity: synthesis of a photoactivatable psoralen derivative conjugated to insulin. Biochem Biophys Res Commun. 1986 Dec; 141(2):502-9.

53 Yoshimasa Y, Namba Y, Hanaoka M, Kohno M, Okamoto M, Hattori M, et al. A new approach to the detection of autoantibodies against insulin receptors that inhibit the internalization of insulin into human cells. Diabetes. 1984 Nov;33(11):1051-4.

54 Poznansky MJ, Singh R, Singh B, Fantus G. Insulin: carrier potential for enzyme and drug therapy. Science. 1984 Mar;223(4642):13046.

55 Jeffcoat R. The biosynthesis of unsaturated fatty acids and its control in mammalian liver. Essays Biochem. 1979;15:1-36.

56 Gross GE, Boldt DH, Osborne CK. Perturbation by insulin of human breast cancer cell cycle kinetics. Cancer Res. 1984 Aug;44(8): 3570-5.

57 Papa V, Pezzino V, Costantino A, Belfiore A, Giuffrida D, Frittitta L, et al. Elevated insulin receptor content in human breast cancer. J Clin Invest. 1990 Nov;86(5):1503-10.

58 Yee D. The insulin-like growth factors and breast cancer-revisited. Breast Cancer Res Treat. 1998 Feb;47(3):197-9.

59 Toth C, Clemens Z. Halted progression of soft palate cancer in a patient treated with the paleolithic ketogenic diet alone: a 20-months follow-up. Am J Med Case Rep. 2016;4(8): 288-92.

60 Schmidt M, Pfetzer N, Schwab M, Strauss I, Kämmerer U. Effects of a ketogenic diet on the quality of life in 16 patients with advanced cancer: A pilot trial. Nutr Metab (Lond). 2011 Jul;8(1):54.

61 Rieger J, Bähr O, Maurer GD, Hattingen E, Franz K, Brucker D, et al. ERGO: a pilot study of ketogenic diet in recurrent glioblastoma. Int J Oncol. 2014 Jun;44(6):1843-52.

62 Seyfried TN. Case studies and personal experiences in using the ketogenic diet for cancer management, in cancer as a metabolic disease: on the origin, management and prevention of cancer. Hoboken, NJ, USA: John Wiley \& Sons, Inc.; 2012. https://doi.org/10.1002/ 9781118310311.

63 Fine EJ, Segal-Isaacson CJ, Feinman RD, Herszkopf S, Romano MC, Tomuta N, et al. Targeting insulin inhibition as a metabolic therapy in advanced cancer: a pilot safety and feasibility dietary trial in 10 patients. Nutrition. 2012 Oct;28(10):1028-35. 
64 Champ CE, Palmer JD, Volek JS, WernerWasik M, Andrews DW, Evans JJ, et al. Targeting metabolism with a ketogenic diet during the treatment of glioblastoma multiforme. J Neurooncol. 2014 Mar;117(1):125-31.

65 Seyfried TN, Yu G, Maroon JC, D’Agostino DP. Press-pulse: a novel therapeutic strategy for the metabolic management of cancer. Nutr Metab (Lond). 2017 Feb;14(1):19.

66 He M, Sun J, Zhao D, He H, Wang B, Xu L, et al. Modified-FOLFIRINOX combined with deep regional hyperthermia in pancreatic cancer: a retrospective study in Chinese patients. Int J Hyperthermia. 2019;36(1):394-402.

67 Fan YF, Qin Y, Li DG, Kerr D. Retrospective Clinical Study of Advanced Pancreatic Can- cer Treated With Chemotherapy and Abdominal Hyperthermia. J Glob Oncol. 2018 Sep;4(4):1-4.

68 Roesch M, Mueller-Huebenthal B. Review: the role of hyperthermia in treating pancreatic tumors. Indian J Surg Oncol. 2015 Mar; 6(1):75-81.

69 Tschoep-Lechner KE, Milani V, Berger F, Dieterle N, Abdel-Rahman S, Salat C, et al. Gemcitabine and cisplatin combined with regional hyperthermia as second-line treatment in patients with gemcitabine-refractory advanced pancreatic cancer. Int J Hyperthermia. 2013;29(1):8-16

70 Ishikawa T, Kokura S, Sakamoto N, Ando T, Imamoto E, Hattori T, et al. Phase II trial of combined regional hyperthermia and gemcitabine for locally advanced or metastatic pancreatic cancer. Int J Hyperthermia. 2012; 28(7):597-604.

71 Ishikawa T, Kokura S, Oyamada H, Inui M, Okita M, Isozaki Y, Nagao Y, et al. Effects of sequential combination of hyperthermia and gemcitabine in the treatment of advanced unresectable pancreatic cancer: a retrospective study. Thermal Med. 2008;24(4):131-9.

72 Iyikesici MS. Feasibility study of metabolically supported chemotherapy with weekly carboplatin/paclitaxel combined with ketogenic diet, hyperthermia and hyperbaric oxygen therapy in metastatic non-small cell lung cancer. Int J Hyperthermia. 2019;36(1):446-55. 